\title{
Crinamine from Crinum asiaticum var. japonicum Inhibits Hypoxia Inducible Factor-1 Activity But Not Activity of Hypoxia Inducible Factor-2
}

\author{
Young Ho KIm, ${ }^{*, a, b, c}$ Eun Jung PARK, ${ }^{c}$ Mi Hyun PARK, ${ }^{a}$ Uranchimeg BADARCH, ${ }^{c}$ \\ Girma Moges Woldemichael, ${ }^{b}$ and John Albert Beutler ${ }^{b}$ \\ ${ }^{a}$ College of Pharmacy, Chungnam National University; Daejeon 305-764, Korea: ${ }^{b}$ Molecular Targets Development \\ Program; NCI-Frederick, Frederick, Maryland 21702, U.S.A.: and ${ }^{c}$ SAIC-Frederick, Inc.; NCI-Frederick, Frederick, \\ Maryland 21702, U.S.A. Received May 20, 2006; accepted August 1, 2006
}

In a search for natural product inhibitors of hypoxia inducible factor-1 (HIF-1) function, crinamine (1), a crinane type alkaloid, showed potent dose dependent inhibition $\left(\mathrm{IC}_{50}=2.7 \mu \mathrm{M}\right)$ of HIF-1 $\alpha$ in a cell-based reporter gene assay. Crinamine (1) was isolated from the aerial parts of Crinum asiaticum var. japonicum together with lycorine (2), norgalanthamine (3) and epinorgalanthamine (4). The other components $(2-4)$ showed no significant inhibition of HIF-1 $\alpha$ induced transcriptional activity.

Key words crinamine; Crinum asiaticum var. japonicum; HIF1- $\alpha$; HRE assay

Hypoxia inducible factor-1 (HIF-1) activates the transcription of genes involved in crucial aspects of cancer biology including angiogenesis, cell survival, and glucose metabolism. HIF-1 is a heterodimeric protein complex that is composed of two members of the basic helix-loop-helix-Per-ARNT-Sim (bHLH-PAS) domain family, namely HIF- $1 \alpha$ and HIF- $1 \beta$ (or ARNT, aryl hydrocarbon nuclear translocator). ${ }^{1)}$ In contrast to the constitutively expressed HIF- $1 \beta$ subunit, HIF- $1 \alpha$ is an oxygen labile protein, which is targeted for degradation through proline hydroxylation and then ubiquitination in normoxia. ${ }^{2}$ HIF- $1 \alpha$ is stabilized in response to hypoxia or iron chelators and is then capable of dimerization with HIF-1 $\beta$. The HIF-1 complex binds the hypoxia response element (HRE), thereby activating the expression of numerous hypoxia-response genes. $^{3-5}$ ) Overexpression of HIF-1 $\alpha$ in human cancers ${ }^{6)}$ and the importance of hypoxia in the tumor microenvironment indicate the potential of HIF-1 as a target of cancer therapy. Inhibition of HIF-1 function in tumors has been shown to attenuate or suppress tumor growth in experimental xenograft models. ${ }^{7,8)}$ Therefore, small molecule HIF1 inhibitors from natural products have potential as molecularly targeted cancer therapeutics. Several HIF-1 inhibitors such as apigenin, ${ }^{9,10)}$ laurenditerpenol ${ }^{11)}$ and emetine ana$\operatorname{logues}{ }^{12)}$ have been reported from natural sources.

Crinum asiaticum var. japonicum (Amaryllidaceae) grows wild only in Korea and Japan. Phytochemical studies on this plant reported several phenanthridine alkaloids, triterpene alcohols and flavonoids. ${ }^{13-15)}$ Alkaloids isolated from the bulbs of the tribe Amaryllidaceae have shown various pharmacological effects, such as antiviral, ${ }^{16)}$ antimalarial, ${ }^{17)}$ cytotoxic, ${ }^{15,17,18)}$ and antineoplastic activities, ${ }^{19)}$ as well as effects on disease of the nervous system. ${ }^{20)}$ As part of our ongoing molecularly targeted screening projects to develop anticancer and antiviral drugs from natural products, we isolated crinamine $(\mathbf{1})^{16)}$ from the aerial part of $C$. asiaticum var. japonicum together with lycorine $(\mathbf{2}),{ }^{15)}$ norgalanthamine $(3),{ }^{21)}$ and epinorgalanthamine (4). ${ }^{22)}$ Of these compounds, crinamine (1) inhibited HIF-1 $\alpha$ transcription activity significantly in a dose-dependent manner in a cell-based assay.

\section{MATERIALS AND METHODS}

General Procedure Melting points were measured on an electrothermal melting point apparatus and were uncorrected. Optical rotations were measured with a PerkinElmer 241 polarimeter. ${ }^{1} \mathrm{H}$ - and ${ }^{13} \mathrm{C}-\mathrm{NMR}$ spectra were obtained on a Bruker DRX-300 NMR spectrometer. FAB-MS was measured on a JMS-HX/HX 110 A tandem mass spectrometer.

Plant Material The aerial parts of Crinum asiaticum var. japonicum were collected at the island of Jeju (Korea) during August 1998 and dried at room temperature. A voucher specimen (CNU 98105) was deposited at the herbarium in the College of Pharmacy, Chungnam National University, Korea.

Isolation of Alkaloids Crinamine was isolated from the aerial parts of Crinum asiaticum var. japonicum together with lycorine, norgalanthamine and epinorgalanthamine. Structures of the isolated compounds were confirmed by comparison of spectroscopic and other physical properties reported previously. ${ }^{13,15,22)}$

Crinamine (1): White needle crystal, mp 196-197 ${ }^{\circ} \mathrm{C}$. $[\alpha]_{\mathrm{D}}^{27}+106.7^{\circ} \quad(c=0.15, \quad \mathrm{MeOH}) . \quad$ FAB-MS $m / z: 302$ $[\mathrm{M}+\mathrm{H}]^{+}$.

Lycorine (2): White powder, mp $223-228^{\circ} \mathrm{C} . \quad[\alpha]_{\mathrm{D}}^{27}$ $-86.7^{\circ}(c=0.3, \mathrm{MeOH})$. FAB-MS $m / z: 288[\mathrm{M}+\mathrm{H}]^{+}$.

Norgalanthamine (3): Colorless crystal, mp $179-181^{\circ} \mathrm{C}$, $[\alpha]_{\mathrm{D}}^{27}-92.7^{\circ}(c=0.3, \mathrm{MeOH})$. FAB-MS $m / z: 274[\mathrm{M}+\mathrm{H}]^{+}$.

Epinorgalanthamine (4): White amorphous powder, $[\alpha]_{\mathrm{D}}^{27}$ $-133.3^{\circ}(c=0.03, \mathrm{MeOH})$. FAB-MS $m / z: 274[\mathrm{M}+\mathrm{H}]^{+}$.

Assay for Inhibition of HIF-1 Induced Gene Transcription The luciferase assay was modified to 96-well plate format from the previously described method. ${ }^{23)}$ In brief, U251HRE and U251-pGL3 cell as a control cell line were inoculated onto 96-well plates at 10000 cells/well and incubated for $24 \mathrm{~h}$. Compounds at the appropriate concentrations were added in a volume of $100 \mu \mathrm{l}$ new media and incubated for $18 \mathrm{~h}$ in both hypoxic and normoxic conditions. Topotecan at a final concentration of $0.5 \mu \mathrm{M}$ was used as a positive control. Experiments were repeated at least three times. Luminescence was measured with $50 \mu \mathrm{l}$ of Britelite $^{\mathrm{TM}}$ luciferase reagent (PerkinElmer Life Sciences, Boston, MA, U.S.A.). The inhibition activity was expressed as relative luciferase 
units compared to an untreated control in hypoxia. Cytotoxicity was assayed using the SRB assay as described previously. ${ }^{24)}$

Assay for Inhibition of HIF-2 Induced Gene Transcription The assay was performed as recently described, ${ }^{25}$ briefly, the human renal clear cell carcinoma cell line 786-0 was stably transfected with a luciferase reporter construct to generate the cell line 786-0 5xVHRE-Luc with 5 copies of the VEGF HRE modulating minimal promoter activity and the control cell line 786-0 LLuc with the constitutively active cytomegalovirus promoter. Prior to exposure to test compounds, cells were harvested by trypsinization, spun down and resuspended in phenol red-free DMEM medium supplemented with $10 \%$ fetal bovine serum (FBS). Plates were seeded at 5000 cells per well in $27 \mu \mathrm{l}$ medium in a 384-well plate using a $\mu$ Fill microplate liquid dispenser (BioTek, Winooski, VT, U.S.A.) and incubated overnight before compound treatment. Actinomycin D at a final concentration of $0.5 \mu \mathrm{g} / \mathrm{ml}$ was used as a positive control. $100 \mathrm{~mm}$ stock solutions of the test compounds were prepared in DMSO and appropriate amounts were aliquoted into culture medium to prepare test compound dilutions at 10 times the final concentrations. For compound treatment, $3 \mu \mathrm{l}$ of test compounds in culture medium were added into each well using a Biomek FX (Beckman Coulter, Fullerton CA, U.S.A.) automated liquid handling workstation. Final test concentrations ranged between 0.01 and $100 \mu \mathrm{m}$. Thirty microliters of SteadyLite luciferase assay reagent (\#6016987, Perkin-Elmer, Boston, MA, U.S.A.) was added to each well using a $\mu$ Fill microplate dispenser and luminescence measurements were made after $15 \mathrm{~min}$ of incubation at room temperature. Data were collected from at least two independent experiments, with four or more replicates per experiment.

Western Blot of HIF-1 $\boldsymbol{\alpha}$ U251 human glioma cells were maintained in RPMI 1640 supplemented with 5\% heatinactivated fetal bovine serum (FBS), penicillin $(50 \mathrm{IU} / \mathrm{ml})$, streptomycin $(50 \mu \mathrm{g} / \mathrm{ml})$ and $2 \mathrm{~mm}$ glutamine. Human embryonic kidney 293 cells were grown in DMEM with 10\% FBS under the same conditions. Various concentrations $(2,10$, $20 \mu \mathrm{M})$ of crinamine and topotecan as a positive control were incubated for $30 \mathrm{~min}$ with both U251 and 293 cells and treated in either hypoxic or normoxic conditions for 8 and $24 \mathrm{~h}$. Cells were harvested with RIPA buffer containing protease inhibitors. The protein content of cell lysates was measured by Bradford's method and $80 \mu \mathrm{g}$ of protein samples were analyzed by immunoblotting with anti-mouse-HIF-1 $\alpha$ monoclonal antibody (BD transduction laboratories ${ }^{\mathrm{TM}}$, San Jose, CA, U.S.A.). Experiments were repeated at least three times.

60 Cell Line Assay Compounds were tested in the routine NCI 60 human tumor cell line assay with the highest concentration of $100 \mu \mathrm{M}^{26)}$ Data represents single tests.

\section{RESULTS AND DISCUSSION}

Crinamine (1) was isolated from the aerial part of C. asiaticum var. japonicum together with lycorine (2), norgalanthamine (3), and epinorgalanthamine (4) from the $\mathrm{BuOH}-$-soluble fraction (Fig. 1). Crinamine has also been isolated from other Crinum, ${ }^{17,18,20)}$ Brunsvigia, $^{27,28)}$ and Ammocharis ${ }^{29)}$ species in the family Amaryllidaceae. Crinamine was re-

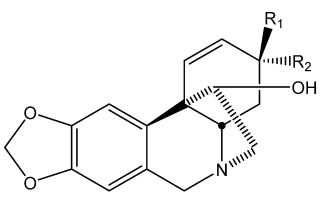

$1 \mathbf{R}_{1}=\mathbf{H}, \mathbf{R}_{2}=\mathrm{OMe}$

$5 \mathbf{R}_{1}=$ OMe, $\mathbf{R}_{2}=\mathbf{H}$

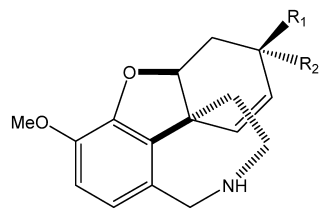

$3 \mathbf{R}_{1}=\mathbf{O H}, \mathbf{R}_{2}=\mathbf{H}$

$4 \mathbf{R}_{1}=\mathbf{H}, \mathbf{R}_{2}=O H$

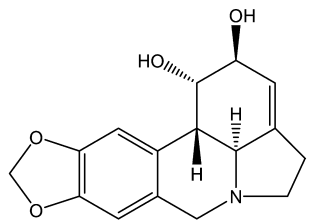

2

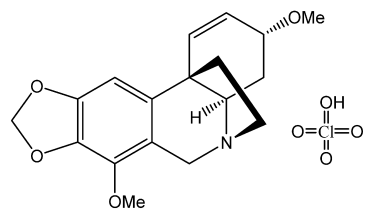

6
Fig. 1. Isolated Compounds from Crinum asiaticum var. japonicum

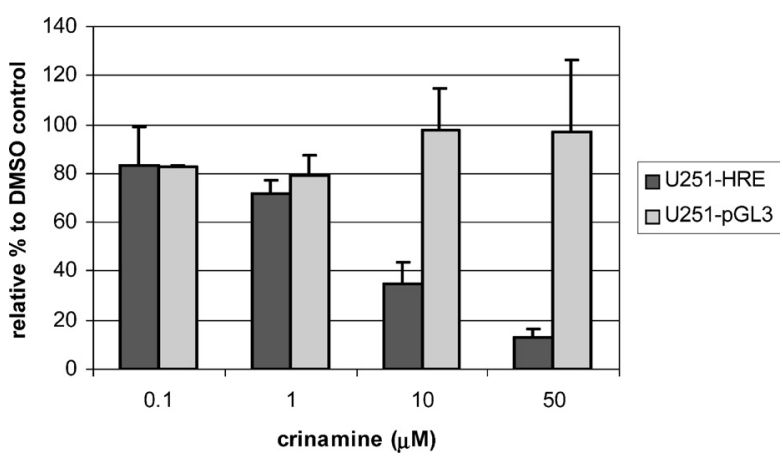

Fig. 2. Cell-Based HRE Assay of Crinamine

ported to have strong cytotoxic, and moderate antimalarial activity. ${ }^{18,28)}$

In screening of HIF-1 inhibitors, crinamine (1) exhibited significant inhibitory activity against the HIF-1 induced transcriptional activation $\left(\mathrm{IC}_{50}: 2.7 \mu \mathrm{M}\right)$ in a concentration dependent manner (Fig. 2) without inhibition in the U251pGL3 control cell line. However, the other compounds $2-\mathbf{4}$ isolated from $C$. asiaticum var. japonicum did not have significant inhibitory activity against HIF-1 activity. In order to compare the inhibitory activity of crinane type compounds, 3-epi-crinamine (5, NSC\# 403140) and buphanidrine perchlorate (6, NSC\# 7519) from the NCI repository were also tested. 3-Epi-crinamine showed slightly reduced inhibitory activity with an $\mathrm{IC}_{50}$ value of $5.4 \mu \mathrm{M}$, while buphanidrine perchlorate did not show any inhibitory activity up to $10 \mu \mathrm{M}$. Interestingly, these HIF-1 inhibitory activities correlated with the results of the NCI 60 cell line assay. Crinamine and 3epi-crinamine showed moderate cytotoxicity in the NCI 60 cell line panel, with $\mathrm{GI}_{50}$ values of $1.9 \mu \mathrm{M}, 16 \mu \mathrm{M}$, respectively, but buphanidrine perchlorate showed no cytotoxic activity (mean $\mathrm{GI}_{50}>81 \mu \mathrm{M}$ ). The relationship between cytotoxicity and inhibitory activity against HIF-1 induced transcriptional activation is not clear, but HIF-1 may play a role in the cytotoxic activity of crinamine.

In order to further study the mechanism of HIF-1 inhibition by crinamine, HIF-1 $\alpha$ protein levels were examined 
under both normoxia and hypoxia by Western blot analysis. Crinamine treatment of U251 and 293 cells at the HIF-1 inhibitory concentration did not affect cell viability, as measured by the SRB assay. The HIF-1 $\alpha$ protein level was not changed in either case (data not shown), which implies that crinamine probably does not act through inhibition of protein synthesis.

In order to investigate specificity versus HIF-1, the inhibitory effect on HIF-2 induced gene transcription using 786-0 reporter cells was also tested with the three crinane type compounds. Interestingly, crinamine and 3-epicrinamine did not show any inhibitory effect on HIF-2 induced gene transcription, thereby indicating that they have a HIF-1 specific inhibitory effect, and demonstrating that the effect was unlikely to be an artifact of the reporter gene system.

Recently, Abdel-Halim et al. showed that crinamine inhibited nitric oxide production $(1.8 \mu \mathrm{M})$ and induced inducible nitric oxide synthase (iNOS) in lipopolysaccharide (LPS)-activated macrophages. ${ }^{18)}$ iNOS is one of the numerous hypoxia-inducible genes. One of its regulatory elements (iNOSHRE) contains a response element with a HIF-1 binding consensus sequence. iNOS-HRE was required for the activation of the iNOS promoter by interferon-gamma plus picolinic acid. ${ }^{29)}$ Other research on myocardial tissues showed that HIF-1 is essential for the hypoxic regulation of iNOS gene expression. ${ }^{31)}$ In addition, iNOS-derived NO is a key factor sustaining HIF-1 activation during hypoxia and reoxygenation. ${ }^{32)}$ Based on these observations, crinamine might be useful in understanding both cytotoxicity, and HIF-1 and iNOS regulation. Further research on crinamine's mechanism of HIF-1 inhibition and its connection to iNOS will be pursued.

Acknowledgments This work was supported by Korea Research Foundation Grant (KRF-2005-013-E00045). This project has been funded in part with federal funds from the National Cancer Institute, National Institutes of Health, under contract N01-CO-12400. The content of this publication does not necessarily reflect the views or polices of the Department of Health and Human Services, nor does mention of trade names, commercial products, or organizations imply endorsement by the U. S. Government. This research was supported in part by the Intramural Research Program of the NIH, National Cancer Institute, Center for Cancer Research. We are grateful to KBSI for NMR spectral measurements. We thank the Drug Synthesis and Chemistry Branch, DTP, NCI for supplying the crinane analogs $\mathbf{5}$ and $\mathbf{6}$ from the NCI repository, and Giovanni Mellilo and Tawnya McKee for helpful discussions.

\section{REFERENCES}

1) Wang G. L., Jiang B. H., Rue E. A., Semenza G. L., Proc. Natl. Acad. Sci. U.S.A., 92, 5510-5514 (1995).

2) Brahimi-Horn C., Pouyssegur J., Crit. Rev. Oncol. Hematol., 53, 115 123 (2005).

3) Semenza G. L., Nat. Rev. Cancer, 3, 721-732 (2003).

4) Semenza G. L., Cell, 107, 1-3 (2001).

5) Harris A. L., Nat. Rev. Cancer, 2, 38-47 (2002).

6) Zhong H., De Marzo A. M., Laughner E., Lim M., Hilton D. A., Zagzag D., Buechler P., Isaacs W. B., Semenza G. L., Simons J. W., Cancer Res., 59, 5830-5835 (1999).

7) Kung A. L., Wang S., Klco J. M., Kaelin W. G., Livingston D. M., Nat. Med., 6, 1335-1340 (2000).

8) Kondo K., Klco J., Nakamura E., Lechpammer M., Kaelin W. G., Jr., Cancer Cell, 1, 237-246 (2002).

9) Liu L. Z., Fang J. Zhou, Q., Hu, X., Shi X., Jiang B. H., Mol. Pharmacol., 68, 635-643 (2005).

10) Osada M., Imaoka S., Funae Y., FEBS Lett., 575, 59-63 (2004).

11) Mohammed K. A., Hossain C. F., Zhang L., Bruick R. K., Zhou Y.-D., Nagle D. G., J. Nat. Prod., 67, 2002-2007 (2004).

12) Zhou Y. D., Kim Y. P., Mohammed K. A., Jones D. K., Muhammad I., Dunbar D. C., Nagle D. G., J. Nat. Prod., 68, 947-950 (2005).

13) Kobayashi S., Ishikawa H., Kihara M., Shing T., Uyeo S., Chem. Pharm. Bull., 35, 2553-2555 (1976).

14) Takagi S., Yamaki M., Yakugaku Zasshi, 97, 1155-1157 (1977).

15) Min B. S., Gao J. J., Nakamura N., Kim Y. H., Hattori M., Chem. Pharm. Bull., 49, 1217-1219 (2001).

16) Gabrielsen B., Monath T. P., Huggins J. W., Kefauver D., Pettit G. R., Groszek G., Hollingshead M., Kirsi J. J., Shannon W. M., Schubert E. M., Dare J., Ugarkar B., Ussery M. A., Phelan M. J., J. Nat. Prod., 55, 1569-1581 (1992).

17) Likhitwitayawuid K., Angerhofer C. K., Chai H., Pezzuto J. M., Cordell G. A., J. Nat. Prod., 56, 1331-1338 (1993).

18) Abdel-Halim O. B., Morikawa T., Ando S., Matsuda H., Yoshikawa M., J. Nat. Prod., 67, 1119-1124 (2004).

19) Pettit G. R., Cragg G. M., Singh S. B., Duke J. A., Doubek D., J. Nat. Prod., 53, 176-178 (1990).

20) Houghton P. J., Agbedahunsi J. M., Adegbulugbe A., Phytochemistry, 65, 2893-2896 (2004)

21) Bastida J., Viladomat F., Llabres J. M., Quiroga S., Codina C., Rubiralta M., Planta Med., 56, 123-124 (1990).

22) Bastida J., Viladomat F., Bergonon S., Fernandez J. M., Codina C., Rubiralta M., Quirion J.-C., Phytochemistry, 34, 1656-1658 (1993).

23) Rapisarda A., Uranchimeg B., Scudiero D. A., Selby M., Sausville E. A., Melillo G., Cancer Res., 63, 4316-4324 (2002).

24) Monks A., Scudiero D., Skehan P., Shoemaker R., Paull K., Vistica D., Hose C., Langley J., Cronise P., Vaigro-Wolff A., J. Natl. Cancer Inst., 83, 757-766 (1991)

25) Woldemichael G. M., Vasselli J. R., Gardella R. S., McKee T. C., Linehan W. M., McMahon J. B., J. Biomol. Screen, in press (2006).

26) Monks A., Scudiero D. A., Johnson G. S., Paull K. D., Sausville E. A., Anticancer Drug Des., 12, 533-541 (1997).

27) Dry L. J., Poynton M., Thompson M. E., Warren F. L., J. Chem. Soc., 1958, 4701-4704 (1958).

28) Campbell W. E., Nair J. J., Gammon D. W., Codina C., Bastida J., Viladomat F., Smith P. J., Albrecht C. F., Phytochemistry, 53, 587-591 (2000).

29) Koorbanally N., Mulholland D. A., Crouch N., Phytochemistry, 54, 93-97 (2000).

30) Melillo G., Taylor L. S., Brooks A., Musso T., Cox G. W., Varesio, L., J. Biol. Chem., 272, 12236-12243 (1997).

31) Jung F., Palmer L. A., Zhou N., Johns R. A., Circ. Res., 86, 319-325 (2000).

32) Natarajan R., Jones D. G., Fisher B. J., Wallace T. J, Ghosh S., Fowler A. A., III, Biochem. Cell Biol., 83, 597-607 (2005). 